\title{
Warehousing performance improvement using Frazelle Model and per group benchmarking: A case study in retail warehouse in Yogyakarta and Central Java
}

\author{
Elisa Kusrini*, Citra Indah Asmarawati, Galuh Masita Sari, Anisa Nurjanah, Alex Kisanjani, Sadiq Ardo Wibowo, and \\ Indro Prakoso \\ Master of Industrial Engineering, Faculty of Industrial Technology, Islamic University of Indonesia, Kaliurang Km 14,5 Yogyakarta, \\ Indonesia
}

\begin{abstract}
Warehouse performance management has an important role in improving logistic's business activities. Good warehouse management could increase profit, time delivery, quality and customer service. This study is conducted to assess performance of retail warehouses in some supermarket located in Central Java and Yogyakarta. Performance improvement is proposed base on the warehouse measurement using Frazelle model (2002), that measure on five indicators, namely Financial, Productivity, Utility, Quality and Cycle time along five business process in warehousing, i.e. Receiving, Put Away, Storage, Order picking and shipping. In order to obtain more precise performance, the indicators are weighted using Analytic Hierarchy Analysis (AHP) method. Then, warehouse performance are measured and final score is determined using SNORM method. From this study, it is found the final score of each warehouse and opportunity to improve warehouse performance using peer group benchmarking
\end{abstract}

\section{Introduction}

Warehousing management becomes very important because it contributes to cost improvement in logistics system (Liviu et al., 2009). Good warehouse management contribute cost and the quality both in terms of service to customers and the quality of the resulting product (Ackah and Eric, 2016; Speh, 2009). One of the best practice in good management warehouse is performance measurement which can be used to improve warehouse to be more effective and efficient. Performance measurement is useful for manager in order to carry out some improvement action base on periodic review.

Base on literature study on warehouse performance, many models and indicators for measuring warehouse performance are existed, that differ in term of time, cost, quality and productivity dimensions (Staudt et al., 2015). Therefore, warehouse managers need to choose which model comply with their warehouse environment. One of the model for measuring warehouse performance that measures operational activity is Frazelle model (2002). This model use measurement metrics that commonly used in industries. The advantage of Frazelle model is comprehensive, since it does not only measures quality, cost, time and productivity dimensions, but also it measures in terms of warehouse activities (receiving, put away, storage, picking, shipping. Therefore this study decide to focus on warehouse performance measurement using Frazelle model (2002) that measure on five indicators, namely Financial, Productivity, Utility,
Quality and Cycle time along with five business process in warehousing, i.e. : Receiving, Put Away, Storage, Order picking and shipping. A case study on warehouse performance measurement in retail warehouse is conducted. Based on the result, then improvement is proposed using benchmarking by comparing warehouse performance with the best performance among peer group.

\section{Literature Review}

Now days, there is growing interest in the analysis and measurement of performance, because performance analysis allows the development of decision support systems for the design, planning and management of enterprise. A performance measurement system can be defined as the set of metrics used to quantify both the efficiency and effectiveness of actions (Neely et al., 1994). Although warehouse performance can be measured in to hard metric (such as order cycle time, fill rates and costs) and soft metric (such as manager's perceptions of customer satisfaction and loyalty (Staudt et al, 2015), however, in general, efficiency and effectiveness is the most widely utilized as a measure of performance (Ammons, 1995; Kusrini et al., 2014).

Warehouse performance measurement has been explored in different ways by researchers. These works differ from one another with respect to the objectives (long- or short-term decisions), the way to measure these objectives (variety of performance indicators), the type of

*Corresponding author: elisakusrini@uii.ac.id 
warehouse systems (distribution centre, cross-dock platforms, etc.), the focus area inside the warehouse (storage, picking, etc.) and the tools used for measurement (statistical tools, mathematical programming, etc.) (Staudt et al., 2015). Warehouse manager needs to choose which type of suitable measurement with their warehouse environment. This is not an easy job since all of the measurement are different (Keebler and Plank, 2009).

Warehouses could have different activities according to product specification, customer requirements and service levels offered. The complexity of the warehouse activities depends mainly on: (i) the number and variety of items to be handled; (ii) the amount of daily workload to be done; and (iii) the number, nature and variety of processes necessary to fulfill the needs and demands of the customers and suppliers (De Koster and Warffemius, 2005). According to Frazelle (2002), warehouse activities are divide into 5 activity, i.e.: receiving, put away, storage, order picking and shipping. Each activity can be measured by using 5 Key Performance Indicator (KPI), namely financial, productivity, utility, quality and cycle time. Therefore there are 25 KPIs for measuring warehouse as depicted in Figure 1

\begin{tabular}{|c|c|c|c|c|c|}
\hline \multicolumn{5}{|c|}{ Table 4-1: Warehouse key performance indicators (Frazelle, 2002, 56) } \\
\cline { 2 - 6 } & Financial & Productivity & Utillization & Quality & Cycle Time \\
\hline Receiving & $\begin{array}{c}\text { Receiving cost } \\
\text { per line }\end{array}$ & $\begin{array}{c}\text { Receipts per } \\
\text { man-hour }\end{array}$ & $\begin{array}{c}\text { \% Dock door } \\
\text { utilization }\end{array}$ & $\begin{array}{c}\text { \%Receipts } \\
\text { processed } \\
\text { accurately }\end{array}$ & $\begin{array}{c}\text { Receipt } \\
\text { processing time } \\
\text { per receipts }\end{array}$ \\
\hline Putaway & $\begin{array}{c}\text { Putaway cost } \\
\text { per line }\end{array}$ & $\begin{array}{c}\text { Putaways per } \\
\text { man-hour }\end{array}$ & $\begin{array}{c}\text { \% Utilization of } \\
\text { putaway labor } \\
\text { and equipment }\end{array}$ & $\begin{array}{c}\text { \% Perfect } \\
\text { putaways }\end{array}$ & $\begin{array}{c}\text { Putaways cycle } \\
\text { time (per } \\
\text { putaway) }\end{array}$ \\
\hline Storage & $\begin{array}{c}\text { Storage space } \\
\text { cost per item }\end{array}$ & $\begin{array}{c}\text { Inventory per } \\
\text { square foot }\end{array}$ & $\begin{array}{c}\text { \% Locations } \\
\text { and cube } \\
\text { occupied }\end{array}$ & $\begin{array}{c}\text { \% Locations } \\
\text { without } \\
\text { inventory } \\
\text { discrepancies }\end{array}$ & $\begin{array}{c}\text { Inventory days } \\
\text { on hand }\end{array}$ \\
\hline $\begin{array}{c}\text { Order } \\
\text { picking }\end{array}$ & $\begin{array}{c}\text { Picking cost per } \\
\text { order line }\end{array}$ & $\begin{array}{c}\text { Order lines } \\
\text { picked per } \\
\text { man-hour }\end{array}$ & $\begin{array}{c}\text { \% Utilization of } \\
\text { picking labor } \\
\text { and equipment }\end{array}$ & $\begin{array}{c}\text { \% Perfect } \\
\text { picking lines }\end{array}$ & $\begin{array}{c}\text { Order picking } \\
\text { cycle time (per } \\
\text { order) }\end{array}$ \\
\hline Shipping & $\begin{array}{c}\text { Shipping cost } \\
\text { per customer } \\
\text { order }\end{array}$ & $\begin{array}{c}\text { Orders } \\
\text { prepared for } \\
\text { shipment per } \\
\text { man-hour }\end{array}$ & $\begin{array}{l}\text { \% Utilization of } \\
\text { shipping docks }\end{array}$ & $\begin{array}{l}\text { \% Perfect } \\
\text { shipments }\end{array}$ & $\begin{array}{c}\text { Warehouse } \\
\text { order cycle time }\end{array}$ \\
\hline
\end{tabular}

Fig 1. Warehouse Key Performance Indicators (Frazelle, 2002)

\section{Research Methods}

\subsection{Research Objects}

Warehouse performance measurement is conducted in four retail/supermarket warehouses in Yogyakarta and Central Java. The retail/supermarket sell the needs of households, schools and offices. This warehouses has an average space ranging from $175 \mathrm{~m}^{2}$ to $200 \mathrm{~m} 2$ and an average 3-5 labor dedicated to this warehouse. In general, business processes in this retail warehouse starts from the goods received and the process of checking goods, the transfer of goods into the warehouse, put the goods into storage racks. The goods in the warehouse is picked and delivered if there is an order from the store.

\subsection{Research Stages}

The stages in this research are as follow: (1) Determine warehouse criteria based on Frazelle model; (2) Identifying importance weight of KPIs (3). Conduct a field survey and measuring warehouse performance (4) Normalize data using SNORM (5) Perform peer group benchmarking.

\section{Results and Discussion}

\subsection{Result}

This research employ criteria base on frazelle model to find warehouse performance and identify opportunity for improvement. In order to identify the importance weight of indicators, Analytic Hierarchy Process (AHP) model is used. A questionnaires of pair wise comparisons among indicators (KPIs) is prepared and a total of four manager of retail warehouse were asked to give their preferences on the questionnaires. The scale of 1 to $9(1=$ equally, 3 = moderate, $5=$ strong, $7=$ very strong, $9=$ extreme) is utilized to rate the preferences of the expert. Consistency Ratio (CR) is used to check the consistency of the comparison. CR less than 0.1 means that comparison is accepted. The results of questionnaires is analyzed using Analytic Hierarchy Process (AHP) model. Analytic Hierarchy Process was first introduced by Thomas L. Saaty in 1971 and became the most widely method for Multiple Criteria Decision Making (MCDM) (Saaty, 2008). The result of importance weight of each KPIs can be seen in Figure 2.

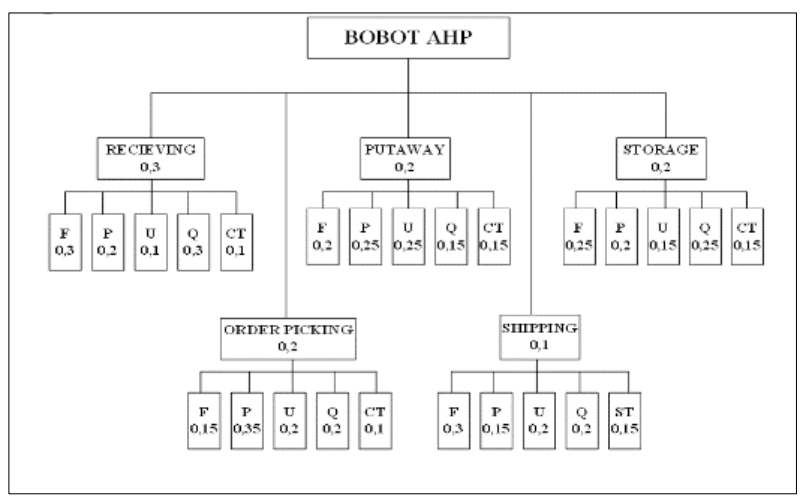

Fig 2. The important weight

The results of field surveys and measuring warehouse performance for four retail warehouse, i e: retail 1 (M1), retail $2(\mathrm{M} 2)$, retail $3(\mathrm{M} 3)$ and retail $4(\mathrm{M} 4)$ as seen in Table 1.

Warehouse performance indicators then scored using standardized method, i.e. SNORM based on benchmark data among warehouses. The process of normalization (SNORM) De Boer (Trienekens and Hvolby, 2000) employed scale of 0 to 100 to get the value of each metric. The final score is obtain by multiplying normalized data with importance weight, as seen on Table 1. 
Table 1. Warehouse Performance Indicators from observation

\begin{tabular}{|c|c|c|c|c|}
\hline Activity & M1 & M2 & M3 & M4 \\
\hline \multicolumn{5}{|l|}{ 1. Receiving } \\
\hline - Financial (Rp/line receiving) & 39.550 & 31.250 & 15.052 & 39.625 \\
\hline - Productivity (box/man-hour) & 106,67 & 216 & 108,4 & 100 \\
\hline - Utilization (\%) & 33,3 & 90 & 98 & 31,3 \\
\hline - Quality (\%) & 98,75 & 100 & 58 & 99 \\
\hline - Cycle Time & 1,5 & 2,08 & 0,56 & 1,5 \\
\hline \multicolumn{5}{|l|}{ 2. Put Away } \\
\hline - Financial (Rp/line putaway) & 46.151 & 62.500 & 38.461 & 79.250 \\
\hline - Productivity (box/man-hour) & 11,4 & 12 & 18 & 16,67 \\
\hline - Utilization (\%) & 95,24 & 90 & 55,78 & 62,5 \\
\hline - Quality (\%) & 98,75 & 100 & 97 & 100 \\
\hline - Cycle Time & 0,0875 & 0,0833 & 0,055 & 0,06 \\
\hline \multicolumn{5}{|l|}{ 3. Storage } \\
\hline - Financial (Rp/line storage) & 13.186 & 16.667 & 8.333 & 23.775 \\
\hline - Productivity (box $/ \mathrm{m}^{2}$ ) & 4,76 & 2,48 & 7,58 & 10 \\
\hline - Utilization (\%) & 70 & 90 & 95 & 50 \\
\hline - Quality (\%) & 90 & 99 & 87 & 99,2 \\
\hline - Cycle Time & 12,5 & 35 & 20 & 14,2 \\
\hline \multicolumn{5}{|l|}{ 4. Order picking } \\
\hline - Financial (Rp/line order picking) & 5.492 & 4.375 & 7.692 & 33.021 \\
\hline - Productivity (box/man-hour) & 119 & 193 & 80 & 125 \\
\hline - Utilization (\%) & 75 & 50 & 90 & 50 \\
\hline - Quality (\%) & 100 & 100 & 94 & 100 \\
\hline - Cycle Time & 0,0083 & 0,005 & 0,0125 & 0,008 \\
\hline \multicolumn{5}{|l|}{ 5. Shipping } \\
\hline - Financial (Rp/line receiving) & 32.965 & 58.333 & 15.384 & 33.021 \\
\hline - Productivity (box/man-hour) & 20 & 112 & 10 & 60 \\
\hline - Utilization (\%) & 50 & 90 & 90 & 26 \\
\hline - Quality (\%) & 100 & 100 & 98 & 100 \\
\hline - Cycle Time & 0,05 & 0,008 & 0,1 & 0,017 \\
\hline
\end{tabular}

The final score of the warehouse is then arranged into the spider diagram as it shows the lowest and the highest score on each indicators along five warehouse activities, as shown on Figure 3.

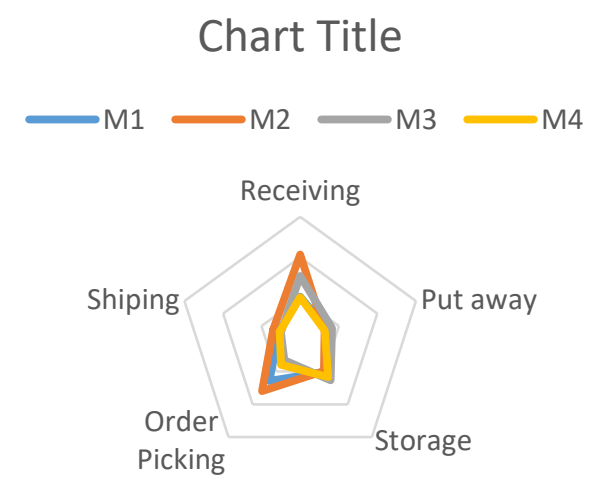

Fig 3. Spider diagram of retail warehouse performance

\subsection{Discussion}

Base on the performance score, it can be seen that M2 warehouse has the highest overall performance value of 59.92. M2 warehouse is superior for receiving, order picking and shipping. This is because in receiving, order picking and shipping process, M2 warehouse maximize its utility that increase its productivity and reduce cost. Especially in order picking, many authors assume that order picking is one of the most labor- and time-intensive internal logistics processes, and that in many cases it is responsible for more than 50 percent of the operating costs of a warehouse (Tompkins et al., 2003; Richards, 2011). Studies suggest that order picking is automatized only to a small degree in many companies, and that more than 80 percent of all orders are picked manually on average (De Koster et al., 2007). Meanwhile, M3 warehouse has the highest score of put away and storage values. This is because there is no stacking of goods in the staging area and using trolley effectively so speeding up the duration 
of the put away process. While good performance in storage due to high inventory turnover, in other words there is no buildup of goods in the warehouse in the long term in M3 Warehouse. This result can be used by the warehouse manager to improve its performance by referring to the best warehouse performance. The highest performance on each activity could be a target setting for other warehouses in order to improve their performance. Opportunity for improvement for each warehouse is described on Table 3.

\section{Conclusions}

This research focus on measuring warehouse performance using Frazelle model (2002). Frazelle model is selected because its metric commonly used in industries and comprehensive, because it not only measures quality, cost, time and productivity dimensions, but also measures in terms of warehouse activities (receiving, put away, storage, picking, shipping). To find performance score of warehouse, the performance indicators are weighted using Analytic Hierarchy Analysis (AHP) method. Warehouse performance are then measured and final score is determined using SNORM method. From this study, it is found the final score of each warehouse and opportunity to improve warehouse performance using peer group benchmarking

\section{References}

1. Ackah, M. R. \& Erick, E. G. (2016). Assessing Inventory management on Performance of the Production Sector in Ghana. Dama International Journal of Researches. Vol 1, issue 7, Page 17-27.

2. Ammons, D. N. (1995). Overcoming the inadequacies of performance measurement in local government: the case of libraries and leisure services. Public Administration Review, 55(1) 37-47.

3. De Koster, M.B.M. andWarffemius, P.M.J. (2005) American, Asian and third-party international warehouse operations in Europe: a comparison. International Journal of Operations and Production Management, 25(8), 762-780.

4. De Koster, R., Le-Duc, T. and Roodbergen, K.J. (2007), "Design and control of warehouse order picking: a literature review", European Journal of Operational Research, Vol. 182 No. 2, pp. 481-501.
5. Frazelle, E., H. (2002). World-Class Warehousing and Material Handling. McGraw-Hill Book Company.

6. Keebler, J. S., and R. E. Plank. (2009). Logistics performance measurement in the supply chain: a benchmark. Benchmarking: An International Journal 16 (6):785-798.

7. Kusrini, E. Subagyo, and Masruroh, N.A (2014). Good criteria for supply chain performance measurement. International Journal of Engineering Business Management, 6:9. doi: 10.5772/58435.

8. Liviu, L., Turdean, A. M. \& Emil, C. (2009). Warehouse Performance Measurement - A Case Study.

9. Neely, A., Gregory,M. and Platts, K. (2005). Performance measurement system design: a literature review and research agenda, International Journal of Operation and Production Management, Vol 25, (2005) 1228 - 1263.

10. Richards, G. (2011), Warehouse Management - A Complete Guide to Improving Efficiency and Minimizing Costs in the Modern Warehouse, Kogan Page, London.

11. Saaty TL.(2008). The analytic hierarchy and analytic network measurenment process: application to decisions under risk. European Journal of Pure and Applied Mathematics 1(1) 122-96.

12. Speh, T. W. (2009). Understanding Warehouse Cost and Risk. Ackherman Warehouse Forum, Vol. 4, No. 7 .

13. Staudt, F.H., Alpan G., Mascolo M., Rodriguez, C.M,T. (2015). Warehouse performance measurement: a literature review. International Journal of Production Research, Vol. 53, No. 18, 5524-5544.

14. Trienekens, J.H. and Hvolby, H.H. (2000). Performance measurement and improvement in supply chain, Proceeding on the third CINET Conference, CI 2000 from Improvement to Inovation, Aalborg 